\title{
Research
}

\section{PROCESS OF ANALYSIS AND DESIGN OF INCOME ACCOUNTING INFORMATION SYSTEM (CASE STUDY OF PT. MARCI)}

\author{
${ }^{1 *}$ Rizki Ahmad Fauzi, ${ }^{2}$ Darwin Marasi Purba \\ Department of Accounting, Universitas Binaniaga Indonesia, Bogor, Indonesia \\ 1)*hafari3327@gmail.com., ${ }^{2}$ mazmur.911516@gmail.com
}

Received: March 17, 2021; Accepted: June 19, 2021; Published: June 30, 2021

${ }^{*}$ Corresponding author

To cite this article: Fauzi, R.A. \& Purba,D.M. (2021). Process of analysis and design of income accounting information system (case study of PT. MARCl) The Accounting Journal of BINANIAGA. 6 (1), 51-60. doi: $\underline{10.33062 / a j b . v 6 i 1.416}$

\begin{abstract}
To increase the competitiveness of a company requires information, including accounting information. With a good accounting information system, it is hoped that the results of physical process efficiency, data updates and accuracy will be achieved. The system design methodology in making the system goes through the stages (1) System Survey (2) System Analysis (3) System Design (4) System Development (5) Testing (6) System Implementation (7) System maintenance. However, with limited time and funds, the researcher completed the research to the system design stage in the form of standard operating procedures (SOP). As for the conclusion, it was found that the work was still inconsistent (same work but implemented in different ways), recording errors, process delays and poor quality.

The system design model that has been prepared by the researcher for the Income Accounting Information System of PT Marci consists of the following procedures: (1) order receipt (2) contract agreement (3) work process (4) billing (5) recording.
\end{abstract}

Keywords: System design, accounting information system, PT MARCI

\section{INTRODUCTION}

In increasing its competitiveness, the companies need information, including accounting information. With a good accounting information system, it is hoped that the results of physical process efficiency, accuracy and data updates will be achieved. However, the existing accounting information system still raises various problems in terms of reporting delays, weaknesses in procedures or systems in the revenue cycle and other cycles, the completeness of the information that is output, and the ability to trace data from the resulting financial statements. These problems are closely related to the information quality requirements required in accounting and finance. Therefore, the problem is considered to be the main problem that must be solved. This problem will be tried to overcome by analyzing the work process and information system needs at PT. MARCl, will do the design of the required information system. In conducting system analysis, the author uses a model-driven method, which is a method that uses diagrams to describe business problems using process modeling and data modeling to describe the requirements for the system in question. In

Rizki Ahmad Fauzi and Darwin Marasi Purba. Process of analysis and design of income accounting information system (case study of PT. MARCl) 
conducting process modeling, the author uses a Structured Analysis approach which is described in the form of a document flowchart. namely a method that uses diagrams to describe business problems by using process modeling and data modeling to describe the requirements for the system in question. In conducting process modeling, the author uses a Structured Analysis approach which is described in the form of a document flowchart, namely a method that uses diagrams to describe business problems by using process modeling and data modeling to describe the requirements for the system in question. In conducting process modeling, the author uses a Structured Analysis approach which is described in the form of a document flowchart.

Significant changes in information and communication technology increase advances in products, technologies and processes. Thus forming a society, that really needs information quickly and validly. The impact of this era, the business world will become more competitive and increasingly stringent. In addition, the business world will increasingly accept changes easily, which of course is accompanied by improvement of strategies and adjusting company operations so that they can remain competitive. Therefore, the output of the accounting information system will be faster, more valid, relevant and at the same time inform alternative decision-making.

The complexity of processing financial transactions must obtain the support of computer software technology that can process computer-based accounting data, so that the information presented can be generated quickly, relevantly, and accurately.

The role of accounting that has been computerized in a real and significant way will certainly support business processes and activities. As a first step in preparing an accounting program, it is necessary to make a Standard Operational Procedure (SOP). Considering the transactions that need to be addressed in every company are sales or income transactions. Because this transaction is very important in receiving funds for the company and this stream became the forerunner of other activities.

The formulation of the problem in this study is how to conduct a company analysis in the context of preparing standard operating procedures so that the initial stages of this accounting application can be an answer and alternative problem solving for the purposes of providing company financial information, recording daily transactions, and preparing financial reports at any time needed.

\section{REVIEW OF LITERATURE}

Furthermore, after taking the condition of the company's data, then try to describe some of the shortcomings that can be made in a reporting system. So far, reporting is based on a simple accounting program, so further development is needed by looking at or developing in software based on the following:

\section{System}

The system is a series of two or more interconnected components, which interact to achieve a goal. Most systems consist of smaller subsystems that support the larger system. (According to Romney and Steinbart 2015:3)

Azhar Susanto (2013: 22) states that the system is a collection or group of subsystems / parts / components or anything, both physical and non-physical that are interconnected with each other and can work together to achieve a certain goal.

Rizki Ahmad Fauzi and Darwin Marasi Purba. Process of analysis and design of income accounting information system (case study of PT. MARCl) 
Meanwhile, according to Carol V. Brown, Daniel W. DeHayes, Jefrrey A. Hoffer, Wainraight E. Martin and William C. Perkins (2012), A system is a set of interrelated components that must work together to achieve some common purpose.

It can be concluded that a system will occur if there is a cooperation between two or more components that are possible or also an interaction between two or more subsystems where the results of the interaction produce a certain output.

\section{Information}

Information is data that has been processed in such a way into a form that is relevant to the recipient and useful in decision making. Data has no value while information already has value. Information is said to be valuable if the benefits are greater than the cost to obtain it. (Fatta Al Hanif, 2007). Information is data that is processed into a form that is more useful and more meaningful for those who receive it (Jogiyanto HM, 2009). The quality of information according to James Hall (2007) is:

a. Relevant, the content of a report or document must work for a purpose.

b. Timely, age of information is a very important factor in determining its usefulness. Information must not exceed the time period of the action it supports.

c. Accuracy, information must be free from significant errors. However, significance is a difficult concept to quantify. This concept has no value meaning that in some situations the information must be completely accurate.

d. Completeness, where all the information that is important for a decision or job must be present.

e. Concise, information should be collected according to user needs. Lower managers, for example, tend to require very detailed information. While top management requires concise information

\section{Information System}

According to Fridayanthie and Charter (2016:65), information systems are activities of procedures organized for use in providing information for the purpose of decision making and control within the organization.

An information system is a set of formal procedures by which data is collected, processed into information and distributed to users (James Hall, 2007). Computer-based information systems in organizations consist of the following components:

a. Hardware, namely hardware components to complete the activities of entering data, processing data, and outputting data

b. Software, namely programs and instructions given to the computer

c. Database, which is a collection of data and information organized in such a way that it is easily accessible to users of information systems.

d. Telecommunications, namely communication that connects system users with computer systems together into an effective work network.

e. Humans, namely personnel from information systems including managers, analysts, programmers, and operators and are responsible for system maintenance.

Meanwhile, according to Raymond McLeod Jr, that computer-based information systems in the future will include Accounting Information Systems, Management Information Systems, Decision Support Systems, Virtual Offices and artificial intelligence. Although Raymond's disclosure has been raised since the 90s, its implementation is not as easy as expected, because until the early 21 st century, its implementation has not been fully implemented.

\section{Accounting Information System}

Rizki Ahmad Fauzi and Darwin Marasi Purba. Process of analysis and design of income accounting information system (case study of PT. MARCl) 
According to Fauziah and Laraswati (2015: 248), "Accounting Information System is a collection of record form arrangements, a set of equipment including computers, executive staff and reports created to transform financial data into information needed by management".

In general, accounting can be defined as an information system that produces reports to interested parties regarding economic activities and company conditions (Warren, Reeve, Fess, 2005:10). Accounting information systems can be defined as components consisting of actors, methods, and procedures for collecting, classifying, summarizing, and reporting information regarding finances and business operations, then processing it into information to be used in carrying out company activities (Warren, Reeve \& Fess). , 2005:42).

Through this accounting information system, several categories of accounting information systems can be formed, such as:

1. Sales / Income Accounting Information System;

2. Cash / Bank Receipt Accounting Information System ;

3. Accounting Information System for Purchase / Procurement of Goods or Services;

4. Cash / Bank Expenditure Accounting Information System;

5. Payroll Accounting Information System;

6. Manufacturing / Cost Accounting Information System; and

7. Basic Accounting Information System.

In this case the author will explore more deeply how to analyze and design a Income Accounting Information System that is applied to PT MARCI which is engaged in warehouse maintenance.

\section{RESEARCH METHODOLOGY}

Research methodology is a research method used to obtain data in order to achieve certain goals. The author takes the method in this writing is a descriptive method, which is a method that shows and describes the situation at the place of observation, conducts research and then carries out an analysis to produce conclusions. The type of research conducted in this study is the primary data source.

\section{Research Design}

In conducting a research, it is very necessary to plan and design, research so that the research carried out can run well and systematically. Research design is all research processes carried out by the author in carrying out research starting from planning to carrying out research carried out at a certain time.

\section{Survey System, Types and Methods of Data Collection}

The data collection method is field research, carried out by conducting a direct review of the object to obtain primary data and secondary data.

a. Primary Data Source

Conducting questions and answers on the parties. This research method is carried out on the object of research, the data and information collected are carried out by:

1) Observations

Observations were carried out on the parties concerned to obtain general data by direct observation and observation.

2) Interview

Conduct questions and answers with interested parties and collect data needed to resolve a problem that occurs.

Rizki Ahmad Fauzi and Darwin Marasi Purba. Process of analysis and design of income accounting information system (case study of PT. MARCl) 
b. Secondary Data Source

The source of secondary data in this research is to obtain documents related to the object under study, which is intended as evidence that the research was actually carried out on companies and books, or searches from the internet.

\section{System Analysis}

In order to design a flowchart or document flow chart, it is necessary to carry out the following analysis:

1. Determine the functions involved in the Income Accounting Information System

2. Determine the information needed by each function involved in receiving inputs, implementing processes and issuing outputs in the form of information, goods or services.

3. What reports will be needed in the output of the income Accounting Information System.

\section{System Design, System Development, Testing, System Implementation and System Maintenance}

The next stage after system analysis is to design a system where in this case the author will make a flowchart and narrative as the output of the results of this research. The development of the system design is in the form of system development, testing, system implementation and system maintenance in the form of applications in the form of further research.

\section{RESULTS AND DISCUSSION}

\section{Company Condition Overview}

PT. MARCI was founded in 2008, and is engaged in research and training, Building Maintenance and General Trading. The company's commitment in accordance with its vision and mission is the creation of an ideal corporate culture, PT. MARCl always tries to use the right methodological basis in various disciplines, so that it produces high quality output and is able to compete in the dynamics of global competition. The combination of experience and knowledge will build a deep understanding of the various studies and activities required. The desire to change and progress that is owned by every institution can be done through a systematic thought process and is based on a measurable analysis. Therefore, "analyzing, thinking, and changing" is a reference for PT. MARCI.

In terms of work experience, this company has not been able to stand well, many things need to be improved, especially with regard to reporting financial accounting information, so we need a program that can help facilitate the work. Furthermore, after seeing the condition of the company's data, then try to describe some of the shortcomings that can be made in a reporting system. So far, reporting is based on a simple accounting program, so further development is needed by viewing or developing in software. However, before software development is made, the first stage is the design of flowcharts for each process, including the Income Accounting Information System.

\section{a. System Proposal}

\section{Income Accounting Information System}

Rizki Ahmad Fauzi and Darwin Marasi Purba. Process of analysis and design of income accounting information system (case study of PT. MARCl) 
The Accounting Journal of BINANIAGA Vol. 06, No. 01, June 2021

p-ISSN: 2527-4309, e-ISSN: 2580-1481

$5^{\text {th }}$ Accreditation Rating: January 14, 2019 - January 13, 2024

After conducting an analysis within the company regarding the condition of financial reporting, here are some things that were submitted for the proposed income accounting information system as in Figure 1:

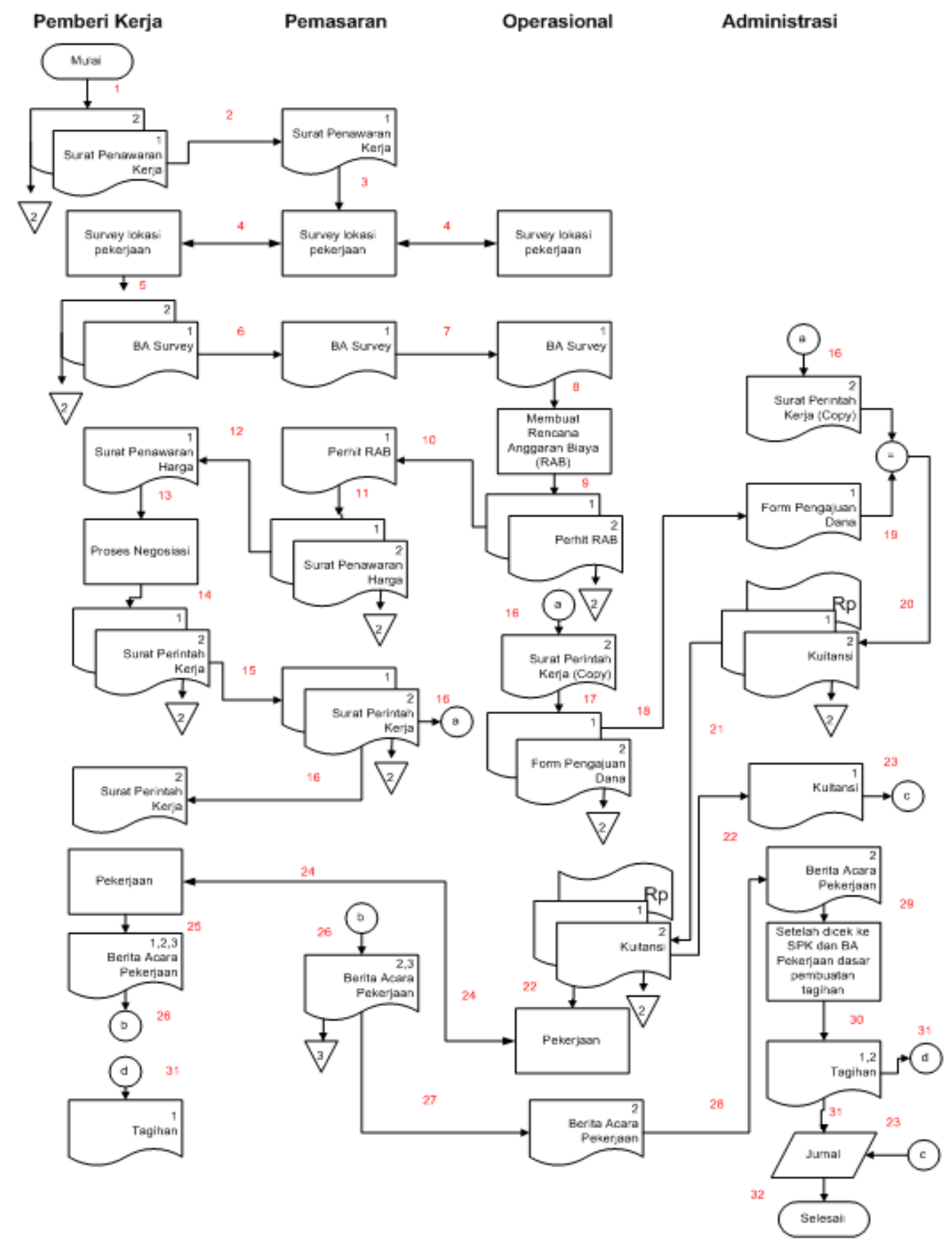

Figure 1. Proposed income accounting information system

Rizki Ahmad Fauzi and Darwin Marasi Purba. Process of analysis and design of income accounting information system (case study of PT. MARCl)

Page : 56 
PT MARCI

Income Accounting Information System

Narrative

\begin{tabular}{|c|c|c|c|}
\hline NO & DESCRIPTION & $\begin{array}{l}\text { PERSON IN } \\
\text { CHARGE }\end{array}$ & DOCUMENT \\
\hline 1 & Preparing Job Offer Letters & Employer & Job Offer Letters \\
\hline 2 & $\begin{array}{l}\text { Receive a Job Offer Letter from the Employer either } \\
\text { in the form of email or via Whatsapp }\end{array}$ & Marketing & Job Offer Letters \\
\hline 3 & Prepare a site survey on job offers from Employers & Marketing & \\
\hline 4 & $\begin{array}{l}\text { Together with the Operational and Employer } \\
\text { functions review the location of work offered to the } \\
\text { company in determining the scope of work } \\
\text { agreement and also the length of work. } \\
\text { This site survey is important in order to determine } \\
\text { the BoQ (Bill Of Quantity) and the required } \\
\text { workforce. }\end{array}$ & Marketing & \\
\hline 5 & $\begin{array}{l}\text { Issuing } 2 \text { copies of the Minutes of Survey which will } \\
\text { later be signed by both parties. The first sheet is } \\
\text { distributed to the marketing function and the second } \\
\text { sheet becomes the Employer's file }\end{array}$ & Employer & Minutes of Survey \\
\hline 6 & Receive Minutes of Survey first sheet from employer & Marketing & Minutes of Survey \\
\hline 7 & $\begin{array}{l}\text { Minutes of Survey (BAS) the first sheet after being } \\
\text { copied, immediately distributed to the Operational } \\
\text { Function }\end{array}$ & Marketing & Minutes of Survey \\
\hline 8 & $\begin{array}{l}\text { Based on the BAS, a Budget Plan (RAB) is } \\
\text { prepared }\end{array}$ & Operational & \\
\hline 9 & $\begin{array}{l}\text { Issuing the RAB in duplicate. The first sheet is } \\
\text { submitted to the Marketing function and the second } \\
\text { sheet becomes the Operations function file }\end{array}$ & Operational & Budget Plan \\
\hline 10 & $\begin{array}{l}\text { Receive RAB calculations from operational } \\
\text { functions }\end{array}$ & Marketing & Budget Plan \\
\hline 11 & $\begin{array}{l}\text { Based on the RAB received from the Operational } \\
\text { Function, a Quotation Letter is made }\end{array}$ & Marketing & Quotation Letter \\
\hline 12 & Submit a Quotation Letter to the Employer & Marketing & Quotation Letter \\
\hline 13 & $\begin{array}{l}\text { Based on the Quotation Letter received from the } \\
\text { vendor, negotiations are carried out }\end{array}$ & Employer & Quotation Letter \\
\hline 14 & $\begin{array}{l}\text { After negotiations and there is an agreement on } \\
\text { price and work, } 2 \text { pieces of Work Order (SPK) are } \\
\text { immediately made. }\end{array}$ & Employer & Work Order \\
\hline 15 & $\begin{array}{l}\text { Receiving SPK in two copies which have been } \\
\text { signed by the Employer. And then sign the SPK }\end{array}$ & Marketing & Work Order \\
\hline
\end{tabular}

Rizki Ahmad Fauzi and Darwin Marasi Purba. Process of analysis and design of income accounting information system (case study of PT. MARCl) 
The Accounting Journal of BINANIAGA Vol. 06, No. 01, June 2021

p-ISSN: 2527-4309, e-ISSN: 2580-1481

$5^{\text {th }}$ Accreditation Rating: January 14, 2019 - January 13, 2024

\begin{tabular}{|c|c|c|c|}
\hline NO & DESCRIPTION & $\begin{array}{l}\text { PERSON IN } \\
\text { CHARGE }\end{array}$ & DOCUMENT \\
\hline 16 & $\begin{array}{l}\text { Send one copy of the SPK which has been signed } \\
\text { by both parties to the Employer. In addition, copying } \\
\text { the SPK and the copies are distributed to the } \\
\text { operational and administrative functions }\end{array}$ & Marketing & Work Order \\
\hline 17 & $\begin{array}{l}\text { Based on the copy of the SPK, it is prepared to } \\
\text { apply for funds through the Procurement Forms in } \\
\text { order to purchase raw materials and pay for labor } \\
\text { and operational fees. The Fund Submission Form is } \\
\text { made in } 2 \text { copies. The first sheet is distributed to the } \\
\text { Administration function and the second sheet is } \\
\text { used as an archive. }\end{array}$ & Operational & Work Order, Procurement Form \\
\hline 18 & $\begin{array}{l}\text { Receive Procurement Forms (FPD) from operational } \\
\text { function. }\end{array}$ & Administration & Procurement Form \\
\hline 19 & $\begin{array}{l}\text { Checking the data contained in the FPD with the } \\
\text { previously received SPK. Therefore, it is very } \\
\text { important that every FPD preparation must include } \\
\text { the SPK number. }\end{array}$ & Administration & Procurement Form, Work Order \\
\hline 20 & $\begin{array}{l}\text { After there is a match between the SPK and FPB } \\
\text { data, money and receipts are prepared }\end{array}$ & Administration & Receipt \\
\hline 21 & $\begin{array}{l}\text { Submit money and two receipts to operational } \\
\text { function }\end{array}$ & Administration & Receipt \\
\hline 22 & $\begin{array}{l}\text { Signing receipts as proof of receipt of money from } \\
\text { the Administration function. The handover of money } \\
\text { and the signing of receipts were directly attended by } \\
\text { the operational and administrative functions. Then } \\
\text { the second sheet of receipt is returned to the } \\
\text { Administration Function }\end{array}$ & Administration & Receipt \\
\hline 23 & $\begin{array}{l}\text { Receipts received directly in the journal and } \\
\text { recorded as part of a project }\end{array}$ & Administration & Receipt \\
\hline 24 & Doing work in the field & Operational & \\
\hline 25 & $\begin{array}{l}\text { After the work is completed, the employer will make } \\
\text { a Minutes of Work (in practice it is an operational } \\
\text { function that makes Minutes). The Minutes of Work } \\
\text { are signed by both parties, namely the employer } \\
\text { and PT Marci. }\end{array}$ & Operational & Minutes of Work \\
\hline 26 & $\begin{array}{l}\text { Furthermore, the first sheet of Minutes of Work } \\
\text { (BAP) is archived by the employer and the second } \\
\text { sheet and the rest is distributed to the Marketing } \\
\text { Function }\end{array}$ & Employer & Minutes of Work \\
\hline 27 & $\begin{array}{l}\text { Distributing BAP sheets } 2 \text { or } 3 \text { to the Operational } \\
\text { Function }\end{array}$ & Marketing & Minutes of Work \\
\hline 28 & Submitting the BAP to the administrative function. & Operational & Minutes of Work \\
\hline 29 & $\begin{array}{l}\text { Based on the BAP received from the operational } \\
\text { function and SPK, } 2 \text { pieces of Invoices are prepared }\end{array}$ & Administration & Minutes of Work \\
\hline 30 & Make a invoice of 2 sheets & Administration & Invoice \\
\hline
\end{tabular}

Rizki Ahmad Fauzi and Darwin Marasi Purba. Process of analysis and design of income accounting information system (case study of PT. MARCI)

Page : 58 


\begin{tabular}{|c|l|c|l|}
\hline NO & \multicolumn{1}{|c|}{ DESCRIPTION } & $\begin{array}{c}\text { PERSON IN } \\
\text { CHARGE }\end{array}$ & \multicolumn{1}{|c|}{ DOCUMENT } \\
\hline 31 & $\begin{array}{l}\text { Journalize income based on invoices and send } \\
\text { invoices to employer }\end{array}$ & Administration & Invoice \\
\hline 32 & Finish & & \\
\hline
\end{tabular}

\section{CONCLUSION AND RECOMMENDATION}

The conclusions in the preparation of this paper are as follows:

a. The functions involved in the company's Income Accounting Information System are: Marketing, Operations and Administration;

b. The procedures that are part of the Income Accounting Information System are (1) Acceptance of Orders by receiving a Job Offer Letter, (2) a contract agreement which is described in the form of a Work Order (3) The process of work which is completed in the form of a Minutes of Work (4) Invoice with issue invoices based on Minutes of Work (5) Recording by journalizing;

c. Documents used in the Accounting Information System are Job Offer Letters, Minutes of Surveys, Budget Plans, QuotationLetters, Procurement Forms, Receipts, Work Orders, Minutes of Work and Invoices.

\section{REFERENCES}

Brown,C.V., DeHayes,D.W., Hoffer,J.A., Martin,W.E. \& Perkins,W.C., (2012), “ Managing Information Technology ", 7th Edition, Pearson Prentice Hall, New Jersey.

Fauziah, M., Dan Laraswati, D., (2015), "Perancang Sistem Informasi Akuntansi Simpan Pinjam Pada Koperasi Pasar Induk Kramat Jati Jakarta, Jurnal Sistem Informasi STMIK Antar Bangsa, ISSN : 2089-8711, Volume IV Nomor 2, Halaman 247-255, Agustus 2015

Fatta, A.H (2007), "Analisis \& Pembuatan Sistem Informasi untuk Keunggulan Bersaing Perusahaan \& Organisasi Modern", Andi Offset, Jogyakarta

Fridayanthie, E. W., \& Charter, J. (2016). Jurnal Techno Nusa Mandiri Vol. XIII, No. 2 September 201663ISSN 1978-2136, "Rancana Bangun Sistem Informasi Simpan Pinjam Karyawan Menggunakan Metode Object Oriented Programming (Studi Kasus: PT. ARTA BUANA SAKTI TANGERANG). Techno Nusa Mandiri, XIII(2), 2. Retrieved from http://ejournal.nusamandiri.ac.id/ejurnal/index.php/techno/article/view/314/25

Hall, J. A., (2007), Sistem Informasi Akuntansi, edisi 4, Alih Bahasa : Dewi Fitriasari dan deny Arnos Kwary., Salemba Empat, Jakarta.

Jogiyanto,J. (2009). Sistem Informasi Manajemen. Yogyakarta: Penerbit Andi.

Raymond McLeod, Jr, (2001)," Sistem Informasi Manajemen”, Edisi 7, alih bahasa : Hendra Teguh, SE.Ak, PT Prehalindo Jakarta

Romney, M. B. dan Steinbart, (2015), "Sistem Informasi Akuntansi", Edisi 13, alihbahasa: Kikin Sakinah Nur Safira dan Novita Puspasari, Salemba Empat, Jakarta.

Rizki Ahmad Fauzi and Darwin Marasi Purba. Process of analysis and design of income accounting information system (case study of PT. MARCl) 
The Accounting Journal of BINANIAGA Vol. 06, No. 01, June 2021

p-ISSN: 2527-4309, e-ISSN: 2580-1481

$5^{\text {th }}$ Accreditation Rating: January 14, 2019 - January 13, 2024

Susanto, A. (2013), "Sistem Informasi Akuntansi”, Lingga Jaya, Bandung.

Warren, .R.F. (2005), "Accounting/Pengantar Akuntansi". 21th edition. Salemba Empat Jakarta.

Rizki Ahmad Fauzi and Darwin Marasi Purba. Process of analysis and design of income accounting information system (case study of PT. MARCl)

Page : 60 